\title{
Olive Leaf Extract Modulates Quorum Sensing Genes and Biofilm Formation in Multi-Drug Resistant Pseudomonas aeruginosa
}

\author{
Nazly R. El-sayed ${ }^{1}{ }^{\oplus}$, Reham Samir ${ }^{2, *}$, Lina Jamil M. Abdel-Hafez ${ }^{1}(\mathbb{D}$ and \\ Mohammed A. Ramadan ${ }^{2}$ \\ 1 Department of Microbiology and Immunology, Faculty of Pharmacy, 6 October University, \\ Giza 12585, Egypt; Nazly.reda.Pha@o6u.edu.eg (N.R.E.-s.); Lina.jamil@ymail.com (L.J.M.A.-H.) \\ 2 Department of Microbiology and Immunology, Faculty of Pharmacy, Cairo University, Cairo 11562, Egypt; \\ mohamed.abdelhalim@pharma.cu.edu.eg \\ * Correspondence: reham.samer@pharma.cu.edu.eg; Tel.: +20-0122-4172-986
}

Received: 29 July 2020; Accepted: 15 August 2020; Published: 19 August 2020

\begin{abstract}
Biofilm acts as a complex barrier against antibiotics. In this study, we investigated the inhibitory activities of Olea europaea (olive) leaves Camellia sinensis (green tea), Styrax benzoin, Ocimum basilicum, Humulus lupulus, Ruta graveolens, and Propolis extracts on the biofilm formation, pyocyanin production, and twitching motility of Pseudomonas aeruginosa isolates. Moreover, we investigated the effect of olive leaf extract on the transcription of some biofilm related genes. A total of 204 isolates of Pseudomonas were collected from different Egyptian hospitals. A susceptibility test, carried out using the disc diffusion method, revealed that $49 \%$ of the isolates were multidrug-resistant. More than $90 \%$ of the isolates were biofilm-forming, of which $26 \%$ were strong biofilm producers. At subinhibitory concentrations, green tea and olive leaf extracts had the highest biofilm inhibitory effects with $84.8 \%$ and $82.2 \%$, respectively. The expression levels of lasI, las $R$, rhlI, and rhlR treated with these extracts were significantly reduced $(p<0.05)$ by around $97-99 \%$ compared to untreated isolates. This study suggests the ability of olive leaf extract to reduce the biofilm formation and virulence factor production of $P$. aeruginosa through the down regulation of quorum sensing (QS) genes. This may help in reducing our dependence on antibiotics and to handle biofilm-related infections of opportunistic pathogens more efficiently.
\end{abstract}

Keywords: Pseudomonas; biofilm; green tea; olive leaves; quorum sensing inhibitors; real-time RT-PCR

\section{Introduction}

Pseudomonas aeruginosa is an emerging opportunistic human pathogen primarily associated with hospital-acquired infection [1]. P. aeruginosa is implicated in the etiology of several diseases including bronchopneumonia, bacteremia, endocarditis, urinary tract infections, burns, and wound infections, etc. [2,3]. The prevalence of infections with P. aeruginosa is caused by the development of various extracellular products and cell-associated virulence factors, including pyocyanin, flagella, pili, and alginate $[4,5]$. Another factor which contributes to P. aeruginosa pathogenesis is its ability to form biofilms when attached to biotic and abiotic surfaces [6]. Biofilm is a complex population of microorganisms enclosed in a matrix [7]. The biofilm extracellular matrix consists of secreted extracellular polymeric substances made of exopolysaccharides (EPS), proteins, nucleic acids, and lipids, which serve as a barrier that keeps bacterial cells together [8]. The matrix is important because it provides structural stability, protects the biofilm, and retards the spread of antibiotics through the biofilm, thereby noticeably increasing the drug resistance among the microbial population $[9,10]$. 
Another virulence factor that $P$. aeruginosa produces is a blue-pigment called pyocyanin. It is a phenazine compound that generates reactive oxygen species [11]. Pyocyanin can easily attack biological membranes and impair cellular respiration by exhaustion at intracellular c-AMP and ATP levels. It is commonly recovered from cystic fibrosis patients infected with P. aeruginosa [4].

Among the cell-associated virulence factors are the cell surface structures, the type IV pili. They most likely promote the adherence to eukaryotic cells and abiotic surfaces [12]. They are also necessary for the flagellum-independent process of translocation which is called twitching motility. Type IV pilus-based twitching motility is sufficient to initiate attachment and production of P. aeruginosa biofilm [13].

Most bacteria regulate their virulence factors via a cell-to-cell signaling mechanism, called quorum sensing (QS). It requires the development of signaling molecules called autoinducers (AIs) [14]. These molecular signals spread throughout the community and interact with their corresponding regulators for collaborative expression of virulence specific genes such as extracellular proteases, efflux pumps, motility, attachment, and biofilm formation [15]. Acyl-homoserine lactones (AHLs) are the most important AIs in Gram-negative bacteria [16]. P. aeruginosa recruits at least four different QS networks interrelated to each other, namely las, $r h l$, iqs, and pqs. These systems possess transcriptional regulators LasR, RhlR, IqsR, and PqsR, respectively, which, after binding to their specific AIs, trigger the expression of selected genes linked to virulence [15] from which, several proteins that are engaged in pathogenicity and the development of biofilms [17]. In addition, transcriptomic data demonstrated the negative regulations of P. aeruginosa QS with laslI, laslR, rhlI, and rhlR under different conditions. Different studies proposed the possibility of the reversion of biofilm formation and how that would impact the progression of infectious diseases [18]. Several natural compounds have been tested experimentally for their ability to suppress the bacterial QS systems [19-21]. Unlike conventional antibiotics which affect certain cellular metabolic process, the quorum sensing inhibitors (QSIs) are believed to hinder bacterial communication without imposing pressure on the bacteria, thus reducing the probability for the emerging of resistant strains existence [22]. As an example of plant-derived compounds, catechin-7-xyloside, sappanol, and butein were capable of interacting with LasR and significantly reduced the biofilm formation, pyocyanin, elastase, and rhamnolipid without influencing the growth of $P$. aeruginosa [23].

The antimicrobial activity of some herbal medicines against different pathogens has been recorded from various countries [24]. Moreover, some natural products, primarily phytochemicals or their derivatives, may also have disturbing effects on quorum sensing (QS) systems [25,26]. Such phytochemicals are less harmful, have high chemical varieties, biochemical precision, and thus have an upper hand over traditional antibiotics [27].

As a new therapeutic approach: RhlR, one of the two acyl-homoserine-lactone circuits that regulate QS in P. aeruginosa, is considered to be a promising target to treat multidrug resistant P. aeruginosa [28]. RhlR is highly influenced by several small regulatory RNAs that adjust virulence factors regulated by QS in P. aeruginosa which are involved in shifting acute infections to chronic diseases [29].

The fast growing antibiotic resistance has directed attention toward nonantibiotic virulence inhibitors. This approach focuses on inhibiting virulence without killing the bacteria. Therefore, quorum sensing inhibitors were extensively studied. Numerous quorum sensing inhibitors have been identified against $P$. aeruginosa to help dealing with multi and pan drug resistant strains.

The objective of this research is to evaluate the impact of plant-derived natural products, as potential inhibitors, on biofilm formation, pyocyanin production, and twitching motility of multidrug resistant Pseudomonas isolates. In addition, transcriptional analysis of selected QS-controlled genes was performed after treatment with plant extracts. 


\section{Results}

\subsection{Bacterial Isolates}

Out of 332 isolates collected from various hospitals in Egypt between October 2016 and March 2018, a total of 91 clinical isolates and 113 environmental isolates were identified as Pseudomonas aeruginosa. A total of 43 (47\%) clinical isolates were collected from urine samples, 25 (27\%) from wounds, 13 (14\%) from sputum samples, 4 (4\%) from bronchoalveolar lavages, 3 (3\%) from blood samples, 2 (2\%) from throat swabs, and $1(1 \%)$ from tracheal aspirate.

\subsection{Antimicrobial Susceptibility Testing}

Antimicrobial susceptibility screening was performed using the disc diffusion method according to the standard Clinical and Laboratory Standards Institute (CLSI), 2016. This study revealed that $49 \%$ of the tested isolates were multidrug-resistant (MDR). The tested isolates showed relatively high resistance to ticarcillin/clavulanic acid and cefepime with 54\% and 50\%, respectively. Additionally, relatively low resistance patterns were registered against colistin (7\%) and tobramycin (18\%), as shown in Table 1.

Table 1. Antimicrobial susceptibility of the tested isolates against respective antibiotics.

\begin{tabular}{cccc}
\hline \multirow{2}{*}{ Antimicrobial Agent } & \multicolumn{3}{c}{ Number (\%) } \\
\cline { 2 - 4 } & Susceptible (s) & Intermediate (I) & Resistant (R) \\
\hline Amikacin (AK) & $141(69)$ & $22(11)$ & $41(20)$ \\
Aztreonam (AT) & $109(53)$ & $55(27)$ & $40(20)$ \\
Cefepime (CPM) & $56(27)$ & $46(23)$ & $102(50)$ \\
Ceftazidime (CAZ) & $114(56)$ & $22(11)$ & $68(33)$ \\
Ciprofloxacin (CIP) & $130(64)$ & $17(8)$ & $57(28)$ \\
Colistin (CL) & $189(93)$ & - & $15(7)$ \\
Gentamicin (GEN) & $147(72)$ & $6(3)$ & $51(25)$ \\
Imipenem (IPM) & $140(68)$ & $17(11)$ & $42(21)$ \\
Levofloxacin (LE) & $133(65)$ & $12(6)$ & $54(47)$ \\
Meropenem (MRP) & $148(72)$ & $64(31)$ & $44(22)$ \\
Piperacillin/Tazobactam (PIT) & $85(42)$ & $46(23)$ & $55(27)$ \\
Ticarcillin/Clavulanic acid (TCC) & $47(23)$ & $3(1)$ & $111(54)$ \\
Tobramycin (TOB) & $165(81)$ & & $36(18)$ \\
\hline
\end{tabular}

\subsection{Biofilm Production}

\subsubsection{Congo Red Assay}

The biofilm formation ability of the tested isolates was primarily screened by Congo red assay, as shown in supplementary Figure S1. The Congo red method detected 187 isolates (92\%) as biofilm producers. In this assay, we could not differentiate between moderate and weak biofilm-forming isolates (Table 2).

Table 2. Screening of 204 isolates for biofilm formation by MTP and CRA methods.

\begin{tabular}{cccccc}
\hline \multirow{2}{*}{ Screening Method } & \multicolumn{5}{c}{ Biofilm Formation N (\%) } \\
\cline { 2 - 6 } & Strong & Moderate & Week & Non & P. aeruginosa (ATCC 12924) \\
\hline MTP & $54(26 \%)$ & $80(39 \%)$ & $50(25 \%)$ & $20(10 \%)$ & OD $595(1.03 \pm 0.035)$ \\
CRA & $52(25 \%)$ & $135(66 \%)$ & $16(8 \%)$ & Intermediate \\
\hline
\end{tabular}

MTP: Microtiter plate method, CRA: congo red agar method, N: number of isolates. Experiments were performed in triplicate and values expressed as the mean \pm standard deviation. 


\subsubsection{Microtiter Plate Method}

The results achieved from the microtiter plate method based on the measured optical denisty (OD) at $595 \mathrm{~nm}$ and compared to the negative control, demonstrated that 184 isolates $(90 \%)$ were biofilm producers, while 20 isolates $(10 \%)$ could not produce any detectable biofilm. This method was able to differentiate between strong, moderate, and weak biofilm-forming isolates, as shown in Table 2.

\subsection{Phenotypic Detection of Other Virulence Factors}

All isolates were tested and compared to twitching motility and pyocyanin production of standard P. aeruginosa (ATCC 12924), but only $85 \%$ showed positive twitching motility and $51.5 \%$ produced pyocyanin pigment.

It worth mentioning that two isolates (C21, E81) were indicated as both strong biofilm producers and of high antibiotic resistance, hence, these isolates were selected for further use in the subsequent experiments.

\subsection{Molecular Characterizations}

The 16S rRNA gene sequence analysis of both tested isolates (C21, E81) matched with the sequence of the Pseudomonas aeruginosa strain ATCC $1014516 \mathrm{~S}$ ribosomal RNA partial sequence with percent identities of $99.05 \%$ and $98.99 \%$, respectively.

\subsection{MIC Determination, and Growth Curve Analysis of Selected Isolates}

The MICs of seven plant extracts against selected Pseudomonas isolates were determined using the broth microdilution method in accordance with the CLSI 2016 recommendations [30], as shown in Table 3. The most effective plant extracts against the tested isolates were the Camellia sinensis (green tea) with MIC value $6.25 \mathrm{mg} / \mathrm{mL}$, followed by Olea europaea (olive) extract with $12.5 \mathrm{mg} / \mathrm{mL}$.

Table 3. Determination of MICs of plant extracts against the selected strong biofilm producer isolates.

\begin{tabular}{cccccccc}
\hline \multirow{2}{*}{ Isolate } & \multicolumn{7}{c}{ MICs of Different Plant Extracts (mg/mL) } \\
\cline { 2 - 8 } & $\begin{array}{c}\text { Camellia } \\
\text { sinensis }\end{array}$ & $\begin{array}{c}\text { Styrax } \\
\text { benzoin }\end{array}$ & $\begin{array}{c}\text { Olea } \\
\text { europaea }\end{array}$ & $\begin{array}{c}\text { Humulus } \\
\text { lupulus }\end{array}$ & $\begin{array}{c}\text { Ocimum } \\
\text { basilicum }\end{array}$ & Propolis & $\begin{array}{c}\text { Ruta } \\
\text { graveolens }\end{array}$ \\
\hline C21 & 6.25 & 25 & 12.5 & 12.5 & 12.5 & 12.5 & 25 \\
E81 & 6.25 & 25 & 12.5 & 12.5 & 12.5 & 12.5 & 25 \\
\hline
\end{tabular}

Additionally, the growth curve analysis, as shown in Supplementary Figure S2, did not expose a significant difference $(p>0.05)$ in the growth of P. aeruginosa C21 and E81 isolates treated with sub-MIC $\left(\frac{1}{2} \mathrm{MIC}\right)$ of each of the tested herbal extracts compared with the growth of the untreated bacterial cultures.

\subsection{Effect of Sub-Inhibitory Concentrations of Tested Extracts on Biofilm Formation}

Biofilm formation, of the clinical (C21) and environmental (E81) P. aeruginosa isoaltes, was evaluated in the absence (negative control) and the presence of tested herbal extracts (1/2 MIC) in a 96-well microtiter using the Microtiter plate method. The sub-MICs (1/2 MIC) of Camellia sinensis, Olea europaea, Styrax benzoin, Humulus lupulus, Ocimum basilicum, Propolis, and Ruta graveolens extracts inhibited the biofilm formation of the clinical (C21) isolate by $84.8 \%, 82.2 \%, 63.7 \%, 48.8 \%, 40.7 \%, 67.2 \%$, and $48.3 \%$, respectively. However, the same extracts inhibited the biofilm formation of the environmental P. aeruginosa isolate (E81) by $82.7 \%, 80.6 \%, 56.3 \%, 52 \%, 50.6 \%, 63.1 \%$, and $42.2 \%$, respectively, compared to the untreated control. Both isolates exhibited significant inhibition in biofilm formation when treated by the sub-MIC of all herbal extracts. Green tea and olive leaf extracts showed the highest inhibitory effects when compared to other plant extracts, as illustrated in Figure 1. 


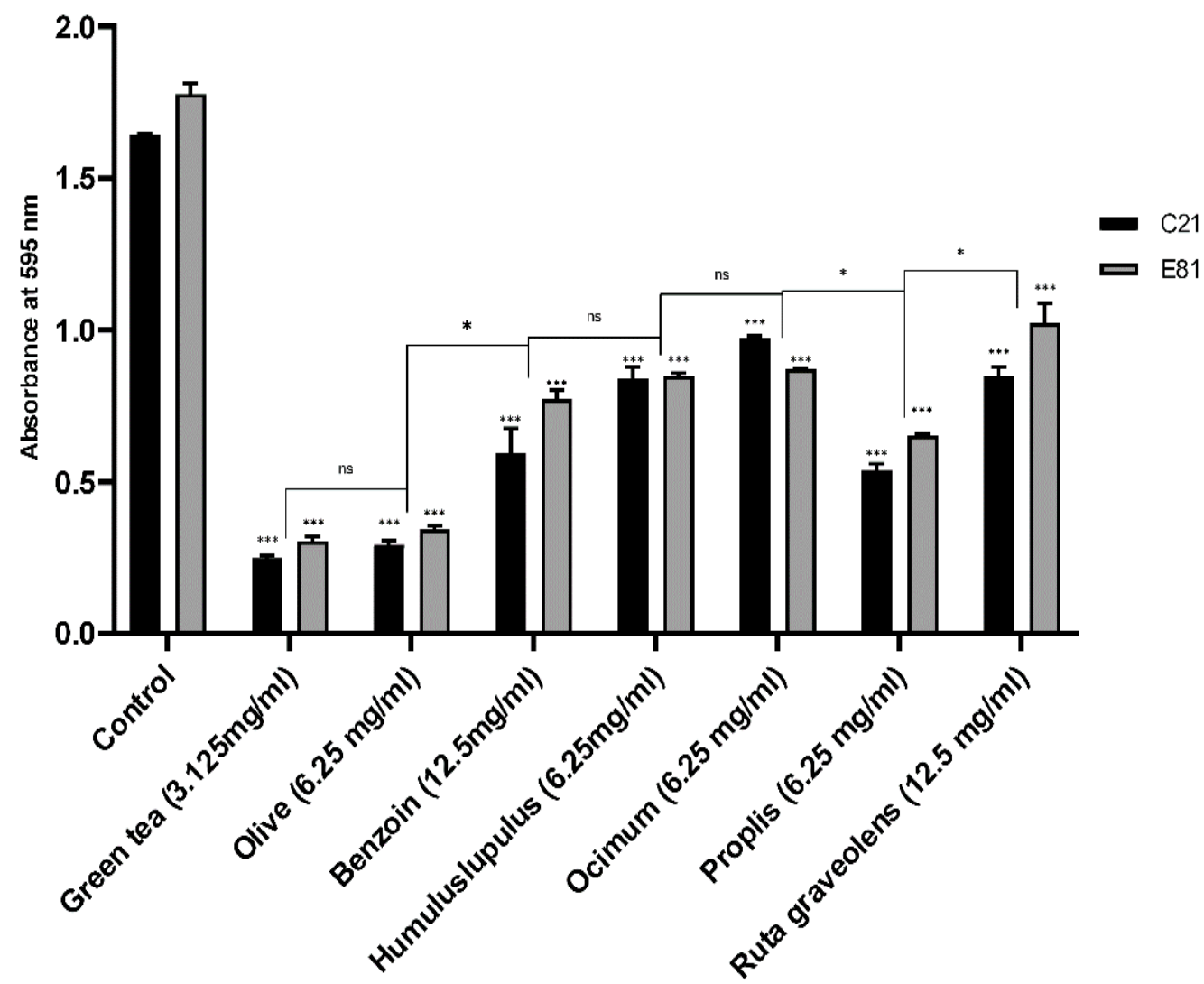

Figure 1. Effect of different herbal extracts on biofilm formation of P. aeruginosa. Bar chart showing the absorbance of P. aeruginosa C21 and E81 in absence and presence of the sub-MIC of Camellia sinensis $(3.125 \mathrm{mg} / \mathrm{mL})$, Olea europaea $(6.25 \mathrm{mg} / \mathrm{mL})$, Styrax benzoin $(12.5 \mathrm{mg} / \mathrm{mL})$, Humulus lupulus (6.25 mg/mL), Ocimum basilicum (6.25 mg/mL), Propolis $(6.25 \mathrm{mg} / \mathrm{mL})$, and Ruta graveolens $(12.5 \mathrm{mg} / \mathrm{mL})$. Biofilm formation was evaluated using the microtiter plate method. Data are an average of three independent experiments. The results are presented by the mean \pm SD. ns $=$ nonsignificant; ${ }^{*}=p<0.05$; $* * *=p<0.001$ : significance was compared to the respective control.

\subsection{Effect of Sub-Inhibitory Concentrations of Tested Extracts on Twitching Motility}

Twitching motility of the clinical isolate $\mathrm{C} 21$ and the environmental isolate E81 was determined in the absence (negative control) and the presence of tested herbal extracts $(1 / 2 \mathrm{MIC})$. The sub-MIC $(1 / 2$ MIC) of Camellia sinensis, Olea europaea, Styrax benzoin, Humulus lupulus, Ocimum basilicum, Propolis, and Ruta graveolens extracts inhibited the development of twitching motility in the clinical isolate (C21) by $93.8 \%, 31.2 \%, 87 \%, 10.8 \%, 39.3 \%, 74.6 \%$, and $6.5 \%$, respectively. However, the sub-MIC of the same extracts inhibited the development of twitching motility in the environmental isolate(E81) by $91.3 \%, 47.3 \%, 83.6 \%, 12.9 \%, 42.9 \%, 75.9 \%$, and $11.9 \%$, respectively, compared to the untreated control. Both isolates showed no significant inhibition in twitching motility when treated by the sub-MIC of Humulus lupulus and Ruta graveolens extracts and significantly inhibited when treated with the sub-MIC of Camellia sinensis, Olea europaea, Styrax benzoin, Ocimum basilicum, and Propolis extracts. Green tea and olive leaf extracts showed the highest inhibitory effects when compared to other plant extracts, as illustrated in Figure 2. 


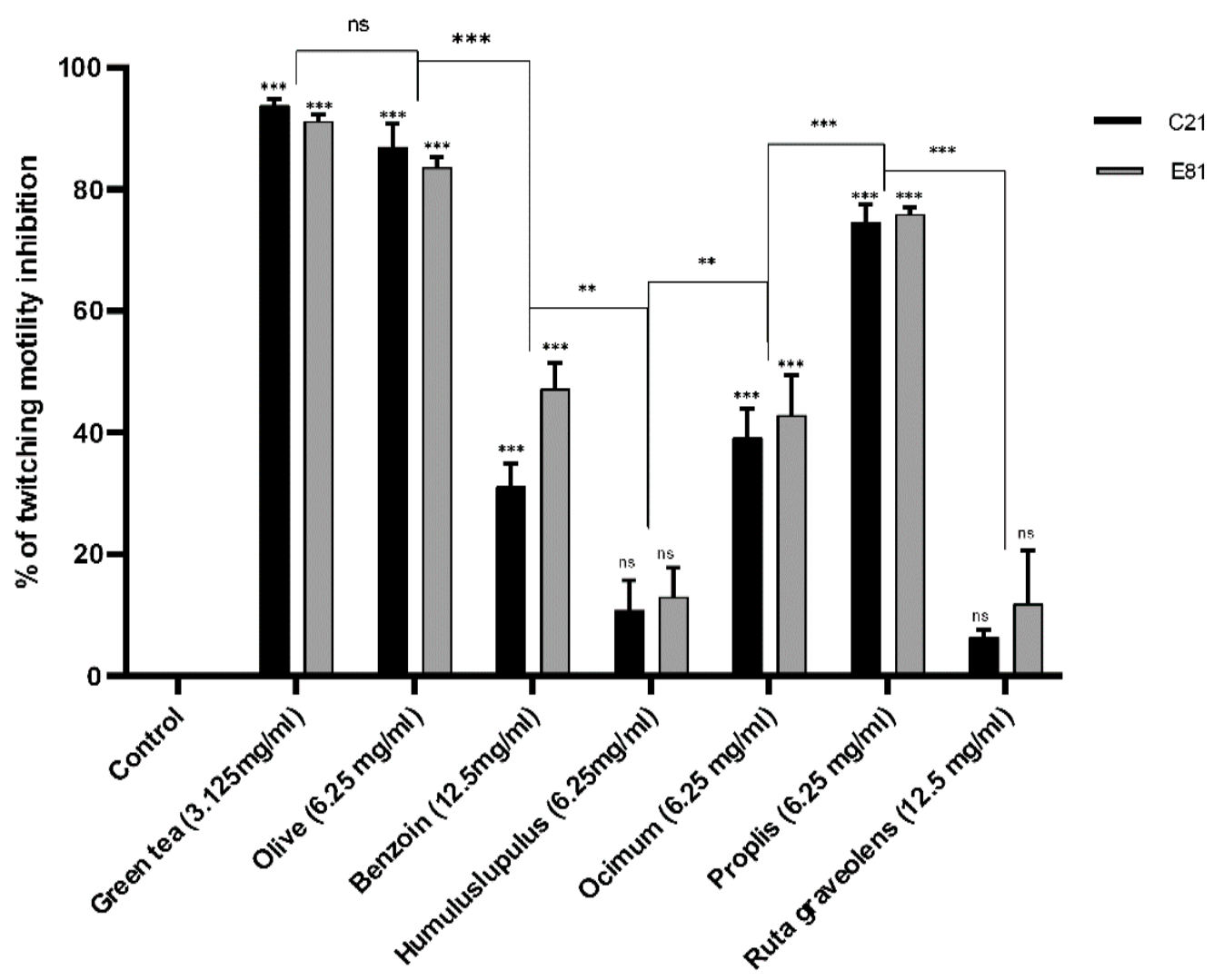

Figure 2. Effect of different herbal extracts on twitching motility of P. aeruginosa. Bar chart showing the percent inhibition of C21 and E81 twitching motility in the absence and presence of herbal extracts Camellia sinensis $(3.125 \mathrm{mg} / \mathrm{mL})$, Olea europaea $(6.25 \mathrm{mg} / \mathrm{mL})$, Styrax benzoin $(12.5 \mathrm{mg} / \mathrm{mL})$, Humulus lupulus $(6.25 \mathrm{mg} / \mathrm{mL})$, Ocimum basilicum $(6.25 \mathrm{mg} / \mathrm{mL})$, Propolis $(6.25 \mathrm{mg} / \mathrm{mL})$, and Ruta graveolens $(12.5 \mathrm{mg} / \mathrm{mL})$. Data are an average of three independent experiments. The results are presented by the mean \pm SD. $\mathrm{ns}=$ nonsignificant; ${ }^{* *}=p<0.01 ;{ }^{* * *}=p<0.001$ : significance was compared to the respective control.

\subsection{Effect of Sub-Inhibitory Concentrations of Tested Extracts on Pyocyanin Production}

Pyocyanin production of the clinical isolate C21 and the environmental isolate E81 were determined in the absence (negative control) and the presence of tested herbal extracts ( $1 / 2 \mathrm{MIC})$ by the chloroform- $\mathrm{HCl}$ extraction method. The sub-MIC (1/2 MIC) of Camellia sinensis, Olea europaea, Styrax benzoin, Humulus lupulus, Ocimum basilicum, Propolis, and Ruta graveolens extracts inhibited the pyocyanin production of the clinical isolate (C21) by $85.4 \%, 40.8 \%, 76.8 \%, 23.5 \%, 31.8 \%, 54.2 \%$, and $15.6 \%$, respectively. However, the sub-MIC ( $1 / 2$ MIC) of the same extracts inhibited the pyocyanin production of the environmental isolate (E81) by $79.8 \%, 47.6 \%, 77.1 \%, 20.3 \%, 41.5 \%, 63.9 \%$, and $11.8 \%$, respectively, compared to the control. Both isolates showed no significant inhibition in pyocyanin production when treated by the sub-MIC of Ruta graveolens extract and significantly inhibited when treated by the sub-MIC of Camellia sinensis, Olea europaea, Styrax benzoin, Humulus lupulus, Ocimum basilicum, Propolis, and Ruta graveolens extracts. Green tea and olive leaf extracts showed the highest inhibitory effects when compared to other plant extracts (Figure 3). 


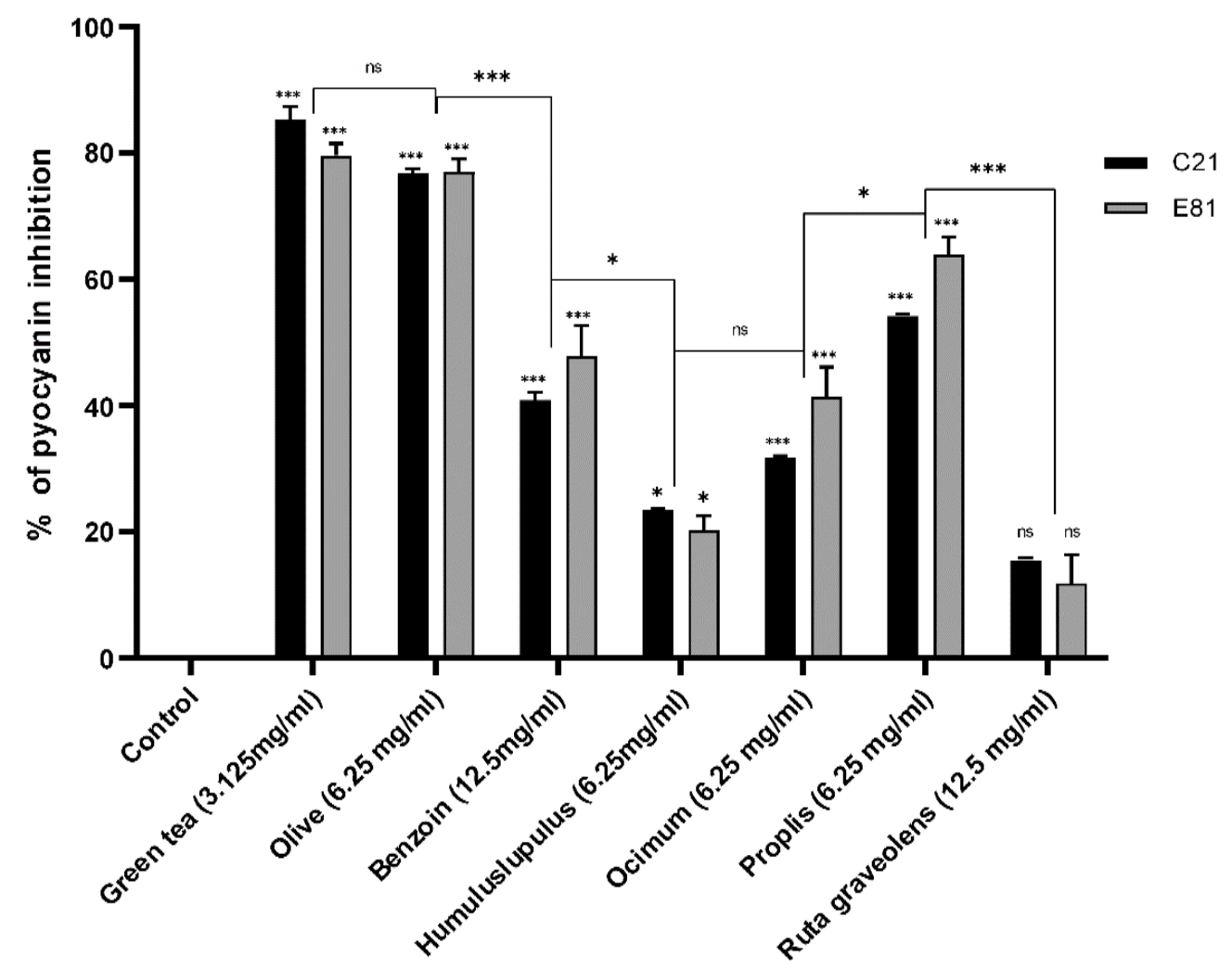

Figure 3. Effect of different herbal extracts on pyocyanin production of P. aeruginosa. Bar chart showing percent inhibition of C21 and E81 pyocyanin production in the absence and presence of herbal extracts Camellia sinensis $(3.125 \mathrm{mg} / \mathrm{mL})$, Olea europaea $(6.25 \mathrm{mg} / \mathrm{mL})$, Styrax benzoin $(12.5 \mathrm{mg} / \mathrm{mL})$, Humulus lupulus (6.25 mg/mL), Ocimum basilicum (6.25 mg/mL), Propolis $(6.25 \mathrm{mg} / \mathrm{mL})$, and Ruta graveolens $(12.5 \mathrm{mg} / \mathrm{mL})$. Pyocyanin production was evaluated by the chloroform- $\mathrm{HCl}$ extraction method. Data are an average of three independent experiments. The results are presented by the mean \pm SD. ns = nonsignificant; ${ }^{*}=p<0.05 ;{ }^{* * *}=p<0.001$ : significance was compared to the respective control.

These results have motivated us to study the impact of green tea and olive leaf extracts on the gene transcription of QS systems (lasI, lasR, rhlI, and rhlR).

\subsection{Effect of Camellia Sinensis and Olea Europaea Leaf Extracts on the QS Genes Transcription Levels of P. aeruginosa $\mathrm{C} 21$}

The influence of the Camellia sinensis and Olea europaea herbal extracts on QS genes transcription was evaluated by fluorescence real-time PCR. The fold change and the percent of inhibition of lasI, lasR, rhlI, and rhlR genes of Camellia sinensis extract-treated clinical isolate (C21) were 99.6\%, 99.3\% 99.4\%, and $99.2 \%$, respectively. Moreover, the fold change of the same genes of Olea europaea extract-treated clinical isolate (C21) was $98.4 \%, 98 \%, 97.4$, and $97.7 \%$, respectively, compared to the housekeeping gene 5s RNA (Figure 4). 


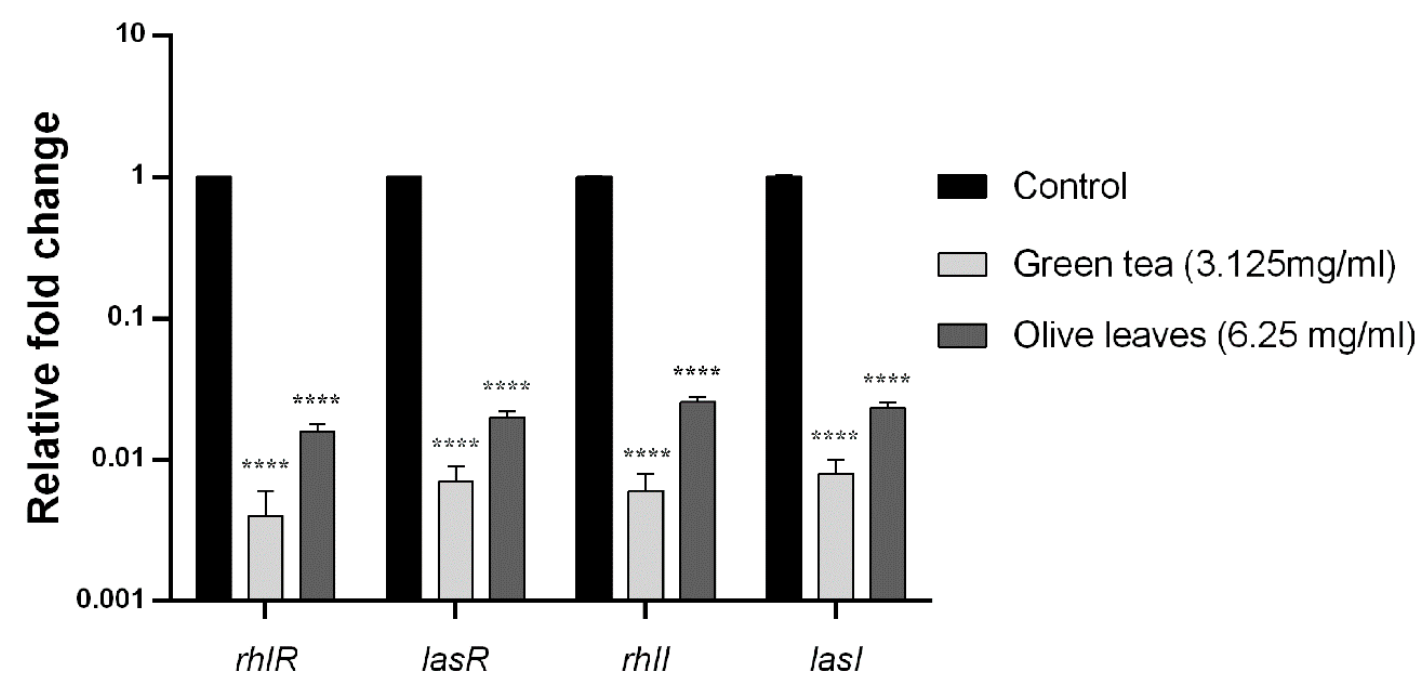

Figure 4. Effect of Camellia sinensis and Olea europaea extracts on the transcription of quorum sensing (QS)-regulated genes of P. aeruginosaC21. Bar chart of the qRT-PCR analysis representing the relative transcription levels of lasI, lasR, rhlI, and rhlR genes treated with sub-MIC levels of Camellia sinensis $(3.125 \mathrm{mg} / \mathrm{mL})$ and Olea europaea $(6.25 \mathrm{mg} / \mathrm{mL})$, normalized with the reference gene $5 \mathrm{~s} R \mathrm{RA}$ and compared to the untreated control. The error bars indicate the standard deviations of three replicates. $* * * *=p<0.0001$ : significance was compared to the respective control.

\subsection{Effect of Camellia Sinensis and Olea Europaea Leaf Extracts on the QS Genes Transcription Levels of} P. aeruginosa E81

The fold change and the percent of inhibition of lasI, lasR, rhlI, and rhlR genes transcription of Camellia sinensis extract-treated environmental isolate (E81) were 91.5\%, 96.2\%, 95.3\%, 95.3\%, and 93.3\%, respectively. Additionally, the fold change of the same genes of Olea europaea extract-treated environmental isolate (E81) was $77.9 \%, 97.9 \%, 95.9 \%, 96.4 \%$, and $93.3 \%$, respectively as shown in Figure 5.

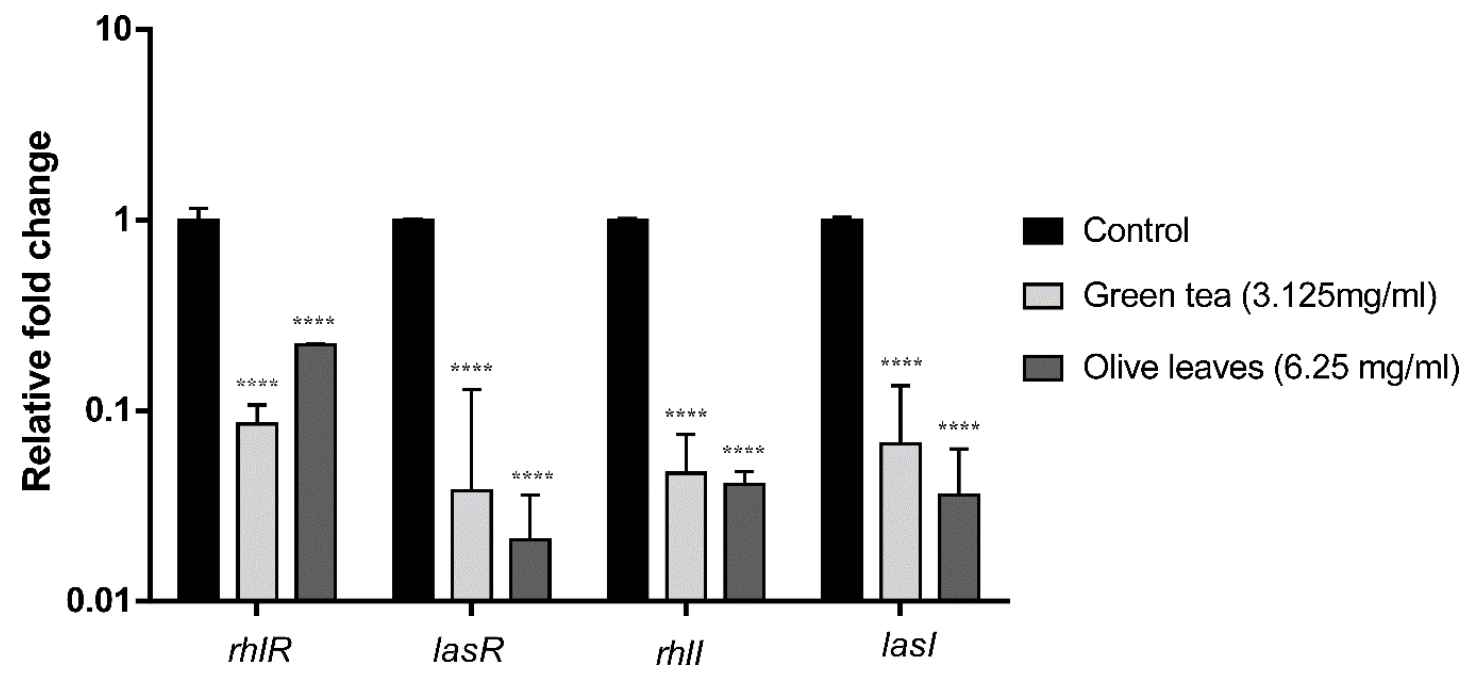

Figure 5. Effect of Camellia sinensis and Olea europaea extracts on the expression of QS-regulated genes of $P$. aeruginosa (E81). Bar chart of the qRT-PCR analysis representing the relative transcription levels of lasI, lasR, rhlI, and rhlR genes treated with sub-MIC levels of Camellia sinensis $(3.125 \mathrm{mg} / \mathrm{mL})$ and Olea europaea $(6.25 \mathrm{mg} / \mathrm{mL})$, normalized with the reference gene $5 s$ RNA and compared to the untreated control. The error bars indicate the standard deviations of three replicates. ${ }^{* * *}=p<0.0001$ : significance was compared to the respective control. 


\section{Discussion}

Pseudomonas aeruginosa is the most prevalent opportunistic pathogen which can lead to nosocomial infections in patients who are immune-compromised or suffer from cystic fibrosis [31]. The resistance of $P$. aeruginosa is causing a devastating problem and limiting therapeutic choices. Moreover, the pathogenicity of this organism is high, due to the production of a set of well-regulated virulence factors.

In our study, the highest resistance was recorded against ticarcillin/clavulanic acid, cefepime, and levofloxacin with 54\%,50\%, and 47\%, respectively. P. aeruginosa possesses numerous intrinsic and acquired resistance mechanisms that are used to overcome most conventional antibiotics and to adapt to newly applied antimicrobial agents. Our findings were consistent with previous studies which observed that the inappropriate use of antibiotics during treatment enhanced the production of MDR- P. aeruginosa isolates, leading to the ineffectiveness of the empiric antibiotic therapy towards this bacterium $[32,33]$. Similar studies on the incidence of resistance to different antibiotics were also reported [34].

On the other hand, the most effective antibiotics against $P$. aeruginosa were colistin with a susceptibility rate of $93 \%$ followed by tobramycin, meropenem, gentamycin, amikacin, and imipenem with $81 \%, 72 \%, 72 \%, 69 \%$, and $68 \%$, respectively. Similar results were recorded by Mustafa and coworkers, as colistin was the most effective antibiotic against $P$. aeruginosa isolates with $92 \%$ susceptibility followed by tobramycin, meropenem, and imipenem 72\%, 63\%, and 48\%, respectively [35]. A previous study conducted in Egypt reported a rise in the numbers of imipenem tolerant P. aeruginosa [36]. Moreover, another study showed that the lowest antibiotic resistance was to imipenem with 7\%, while the highest resistance was to amikacin-48\% [37]. In another study in Egypt, it was found that most of the P. aeruginosa isolates were resistant to ceftazidime followed by levofloxacin and imipenem but with a lower resistance to amikacin [38]. The variation in the resistance rates among previous studies can be due to the differences in geographical distribution, time of sample collection, number of isolates gathered in each study, and the difference in antibiotic strategies adopted in every region.

In our study, the results revealed that about $90 \%$ of the tested isolates (204 isolates) were biofilm producers. The microtiter plate method was considered as the gold standard for this study and was compared with data from the Congo red method. The Congo red method, as a subjective way of testing biofilm formation, was less precise than microtiter plate method, but, on the other hand, it was quicker and required fewer materials for the detection of biofilm formation [39]. Our isolates were categorized according to their biofilm formation ability into $26 \%$ strong biofilm producers, $39 \%$ moderate biofilm producers, $25 \%$ weak biofilm producers, and 10\% could not form any detectable biofilm. Many studies showed differences in the levels of biofilm production by P. aeruginosa isolates [40]. For example, Abdelraheem et al., found that biofilm formation was observed in $27 \%$ Pseudomonas clinical isolates; $14 \%$ developed strong biofilm, 7\% developed moderate biofilm, and 6\% developed weak biofilm [37]. A different study in Egypt demonstrated that biofilm formation was observed in 91.4\% P. aeruginosa isolates; $25.7 \%, 40 \%, 25.7 \%$, and $8.6 \%$ of isolates were strong, moderate, weak, and nonbiofilm producers, respectively [38]. The variation in findings between different studies can be related to several variables, including the differences in type and number of strains gathered in each research study, that eventually lead to differences in the ability of isolates to produce biofilms. In this report, MDR strains were higher among biofilm-producers-with 48.4\% (89/184) — than nonbiofilm producing P. aeruginosa isolates 30\% (6/20). A different study with similar findings noticed that MDR isolates occurred in both biofilm formers and nonbiofilm formers, but most of them were considerably related to the biofilm formers [41]. This may be due to the reduction in growth rates of the bacteria in the biofilm [42], over expression of efflux pump [43], and accelerated expression of resistance genes among bacteria inside the formed matrix $[44,45]$. Besides, this matrix has a protective effect that hinders the penetration of antibiotics into the bacterial cells embedded in the biofilm community [37,46].

From here, the need for new therapeutics that can hinder the biofilm formation and decrease the virulence of $P$. aeruginosa without inducing more resistance is continuously growing. Plant derived 
products are always a good option due to their effectiveness and considerably low side effects. Numerous classes of molecules from natural sources were reported to have both antibiofilm formation and anti-QS properties. We selected Olea europaea (olive) leaves Camellia sinensis (green tea), Styrax benzoin, Ocimum basilicum, Humulus lupulus, Ruta graveolens, and Propolis because they have multiple use in folk medicine as antimicrobial agents or as treatments for wound infections or bed ulcers.

All of the tested plant extracts showed variable antibacterial and antivirulence activities against $P$. aeruginosa isolates. On the other hand, Camellia sinensis and Olea europaea were the most potent antibacterial agents. In addition, their sub-MIC efficiently inhibited biofilm formation and virulence factor production by $P$. aeruginosa and significantly down regulated lasI, lasR, rhlI, and rhlR expression without affecting cell growth. We can relate these effects to their rich constituents of bioactive compounds (Table S2).

The activities of green tea are mainly due to the presence of polyphenols, the most abundant of which is Catechin, particularly epigallocatechin gallate (EGCG) which is the most effective catechin representing $50 \%-80 \%$ of the total catechin content and is known for its inhibitory effect on P. aeruginosa PAO1 virulence factors [47]. Apparently, the observed antibiofilm activity of olea europaea is attributed to the high concentrations of phenolic compounds, such as oleuropein and hydroxy tyrosol [48], or maybe due to the synergistic effect of some phenols contained in the olive extracts. Moreover, phenolic compounds can, potentially, increase the permeability of cell membranes, thus facilitating their rupture [49]. The obtained results also agreed with Yin et al.; they reported that tea polyphenol (TP) exhibited potent antimicrobial activity on all selected isolates and it can also inhibit the development of total protease, elastase, pyocyanin, biofilm formation, and swarming motility in P. aeruginosa [50]. Another report by Qais et al. revealed that the sub-MICs of green tea ethyl acetate fraction (GTEF) inhibited numerous virulence factors of P. aeruginosa PAO1 pyocyanin, pyoverdine, protease, elastase, rhamnolipid production, and swimming motility. Additionally, GTEF demonstrated wide-spectrum antibiofilm action with a more than $80 \%$ reduction in the biofilm formation of the tested organisms [51]. Tea catechin also inhibited the production of violacein in C. violaceum and virulence factors in Pseudomonas aeruginosa PAO1 [52]. Epigallocatechin gallate (EGCG) was found to be the most powerful catechin [47]. In addition, a study conducted by Najee et al. showed that Olea europaea fatty oil inhibited the formation of biofilm on drug-resistant bacterial and fungal pathogens by interacting efficiently with microbial surface structures necessary for growth, such as membrane, and also indicated that it was capable of reducing the motility of the pathogen [53]. Another study showed that the methanolic extract of olive leaves demonstrated essential antioxidant and antibiofilm activities [54]. Additionally, olive leaf is reported to be a potentially inexpensive, sustainable, and plentiful origin of biophenols [55]. Our findings demonstrated that the difference between both tested extracts may be due to their differences in the type and concentration of the active constituents, as well as the polyphenol contents ( 2.93 and $2.07 \mathrm{mg} / \mathrm{kg}$, respectively). The Phytochemical screening for green tea and olive revealed the presence of alkaloids, flavonoids, tannins, saponins, glycoside, terpenoids, and anthocyanin. These results are consistent with other studies that reported the same discovered data [56,57]. These compounds are considered to be bioactive and may be responsible for the activities of both extracts. The down regulation in lasI, las $R, r h l I$, and $r h l R$ genes can be due to their binding affinity to QS regulatory proteins by competitively reducing the attachment of natural autoinducers (AHL).

Many studies examined the effect of other natural sources as anti-QS and antibiofilm on P. aeruginosa. Between them, plant-derived natural flavonoid and phenolic compounds are widely studied for the suppression of P. aeruginosa biofilm [58] and QS regulated virulence factors [59]. Flavonoids such as catechin were observed to suppress the expression of QS genes, and thereby reduce virulence factors in P. aeruginosa PAO1 [52]. Subsequently, other functionally-related flavonols, such as baicalein [60,61], and quercetin [19], are also anti-QS and anti-biofilm compounds. 


\section{Conclusions}

Our study showed that green tea and olive leaf extracts were exhibited to be the most efficient plant extracts against planktonic and biofilm cells. To our knowledge, we report for the first time the ability of olive leaf extract to reduce the biofilm formation of $P$. aeruginosa and virulence factor production through the down regulation of QS genes. Moreover, olive (Olea europaea) leaf is considered as a cheap, abundant, and renewable source of biophenols. These findings may help in reducing our dependence on antibiotics and to handle biofilm-related infections of opportunistic pathogens more efficiently. Further studies are required to distinguish the most important phytochemical compounds and estimate their antibiofilm activities and their mechanisms of action. In addition, in vivo studies are required to enable their application in the prevention and treatment of biofilm-related P. aeruginosa infections.

\section{Materials and Methods}

\subsection{Sample Collection and Growth Conditions}

Throughout the period from October 2016 to March 2018, a total of 332 bacterial cultures were recovered from Qasr El-Aini, October 6 University Hospital, Dar El Salam Cancer Center, Al-Helal hospital, National Cardiology Institute, EL-Nile Badrawy hospital, Abu Al-Reish hospital, Sheikh-Zayed Specialized hospital, National Cancer Institute, and Medical Research Institute-Alexandria, Egypt. These bacterial isolates were recovered from different clinical specimens of hospitalized patients after obtaining informed consents. Clinical specimens were collected from the wound, burn, urine, and sputum. Environmental samples were collected from samples of water and fomites in hospital settings.

Fresh samples were cultivated on Cetrimide agar media, after which isolated species were identified by a regular microbiological technique such as colony morphology (green exopigment Cetrimide agar), Gram staining (Gram-negative rods), and biochemical reactions (oxidase-positive and citrate-positive). Identification at the species level was performed by using the Microbact ${ }^{\mathrm{TM}}$ Gram-negative system. The Microbact system was implemented in compliance with the manufacturer's protocol (Oxoid, UK). Pseudomonas aeruginosa (ATCC 12924) standard strain was used as a positive control.

\subsection{Antimicrobial Susceptibility Testing}

Antibiotic susceptibility patterns of 204 Pseudomonas spp. identified isolates that were examined by the Kirby Bauer Disc Diffusion method depending on the protocol described by the clinical and laboratory standard institute 2016 [30]. Using a sterile loop, 3-5 colonies were picked from each bacterial isolate, and each colony was added to $5 \mathrm{~mL}$ of sterile $0.9 \%$ saline to prepare a standardized $0.5 \mathrm{McF}$ arland bacterial suspension. Sterilized Mueller-Hinton agar (MHA) plates were consistently inoculated with the bacterial suspension using sterile swabs. Antibiotic discs were transferred to the plates' surfaces, and the plates were then incubated at $37^{\circ} \mathrm{C}$ for $24 \mathrm{~h}$. The diameters of the antibiotic inhibition zone were measured after incubation.

Antibiotics were selected, and antimicrobial susceptibility results were interpreted in compliance with recommendations of the CLSI guidelines [30] (Table S1). Antibiotic discs (Hi-media, UK) used in this study were amikacin $(30 \mu \mathrm{g})$, aztreonam $(30 \mu \mathrm{g})$, cefepime $(30 \mu \mathrm{g})$, ceftazidime $(30 \mu \mathrm{g})$, ciprofloxacin $(5 \mu \mathrm{g})$, colistin $(10 \mu \mathrm{g})$, gentamicin $(10 \mu \mathrm{g})$, imipenem $(10 \mu \mathrm{g})$, levofloxacin $(5 \mu \mathrm{g})$, meropenem $(10 \mu \mathrm{g})$, piperacillin + tazobactam $(100 / 10 \mu \mathrm{g})$, ticarcillin/clavulanic acid $(10 / 75 \mu \mathrm{g})$, and tobramycin $(10 \mu \mathrm{g})$.

\subsection{Biofilm Formation Detection Methods}

Two phenotypic methods were used to test the biofilm-forming ability of the Pseudomonas spp. Isolates, namely the Congo red agar method and the Microtiter plate method. 


\subsubsection{Congo Red Agar Method}

The Congo red agar medium consisted of brain heart infusion broth (BHI) (37 gm), agar (10 gm), sucrose $(5 \mathrm{gm})$, and Congo red stain $(0.8 \mathrm{gm})$ per liter of distilled water [62]. Congo red dye was individually prepared and sterilized. After cooling, the dye was eventually added to the sterile BHI agar medium enhanced with sucrose. Plates were inoculated with the tested isolates and incubated at $37^{\circ} \mathrm{C}$ for $24 \mathrm{~h}$. The color of the bacterial colonies was an indication of exopolysaccharide (EPS) production. Isolates with multiple black colonies have been categorized as positive for biofilm production, whereas red and pink colonies have been classified as negative [63].

\subsubsection{Well Microtiter Plates Method}

The in vitro formation of biofilms in 96 well microtiter plates containing Luria Bertani (LB) broth medium was evaluated as follows [64]: Briefly, the overnight broth cultures of the isolated bacterial strains were calibrated, approximately, to $0.5 \mathrm{McF}$ arland turbidity standard, diluted to 1:100 in LB broth, and inoculated into a microtiter plate $(200 \mu \mathrm{L}$ per well). The microtiter plate was incubated at $37^{\circ} \mathrm{C}$ for $24 \mathrm{~h}$. Negative control wells were also included (uninoculated broth). After incubation, the planktonic cells were withdrawn, and were rinsed three times with $200 \mu \mathrm{L}$ of phosphate buffer saline. A volume of $200 \mu \mathrm{L}$ of $0.1 \%$ of crystal violet (CV) was added to each well for 15 min at ambient temperature. The excessive dye was washed away by soaking in distilled water. A volume of $200 \mu \mathrm{L}$ of $33 \%$ acetic acid was added to each well for 10-15 min to solubilize the CV. The optical density (OD) was calculated at $595 \mathrm{~nm}$ in a plate reader using acetic acid as a blank. Each growing strain was tested three times, and the mean was obtained. Then, the assessment of biofilm production was categorized according to the criteria of Stepanovic et al. as follows: ODc was defined as three standard deviations (SDc) above the mean OD of the negative control. Furthermore, the isolates were classified according to resulted OD into categories: nonbiofilm producer $(\mathrm{OD} \leq \mathrm{ODc})$, week biofilm producer $(\mathrm{OD} \leq 2 \mathrm{ODc})$, moderate biofilm producer (2ODc < OD $\leq 4 \mathrm{ODc}$ ), or strong biofilm producer (OD $>4 \mathrm{ODc}$ ) [64].

\subsection{Pyocyanin Assay}

Pyocyanin pigment development for the Pseudomonas spp. isolates was evaluated by using King A agar. Slants of the medium were inoculated and incubated for four days at $30-32{ }^{\circ} \mathrm{C}$. Pyocyanin production was revealed by the addition of $0.5-1 \mathrm{~mL}$ chloroform to the inoculated slants, which were shaken for a few minutes until the pyocyanin was diffused, rendering the solvent blue. After that, the chloroform was acidified with a few drops of $\mathrm{HCl}$, which resulted in a sudden shift in color from blue to red; this shift in color indicated the existence of pyocyanin.

For the quantification of the pyocyanin production, overnight culture was diluted with a ratio of 1:100 with fresh LB broth. Then, $25 \mathrm{~mL}$ of the fresh culture was grown at $37{ }^{\circ} \mathrm{C}, 200 \mathrm{rpm}$ for $24 \mathrm{~h}$. Afterwards, the supernatant was collected after centrifugation at 10,000 rpm for 10 min; then, a volume of $4.5 \mathrm{~mL}$ of chloroform was added to $7.5 \mathrm{~mL}$ of supernatant and vortexed. After the color of chloroform turned to green-blue, the mixture was centrifuged for $10 \mathrm{~min}$ at $10000 \mathrm{rpm}$. A volume of $3 \mathrm{~mL}$ of the resulting blue layer at the bottom (chloroform + pyocyanin) was transferred to a new tube. Subsequently, a volume of $1.5 \mathrm{~mL}$ of $0.2 \mathrm{M} \mathrm{HCl}$ was added to each tube and vortexed. After turning of the blue color into pink (top layer), the mixture was centrifuged for $2 \mathrm{~min}$ at 10,000 rpm, and then $1 \mathrm{~mL}$ from the pink layer was transferred to cuvettes, and the absorbance was measured at $520 \mathrm{~nm}$ spectrophotometrically. Finally, pyocyanin concentration $(\mu \mathrm{l} / \mathrm{mL})$ was calculated by multiplying the $\mathrm{OD}$ at $520 \mathrm{~nm}$ with $17.072 \times 1.5$. All centrifugation steps took place at $4{ }^{\circ} \mathrm{C}$. An amount of $0.2 \mathrm{M} \mathrm{HCl}$ was used as a blank in spectrophotometry [65].

\subsection{Twitching Motility Assay}

A colony of each tested isolate was inoculated deep into the Luria Bertani (LB) agar plate with a sterile toothpick up to the bottom of the petri dish and incubated at $25^{\circ} \mathrm{C}$ for $48 \mathrm{~h}$. The appearance of a 
hazy growth area was noticed and measured at the surface between the agar and petri dishes [66]. The agar plates were gently removed, rinsed with water to eliminate any unattached cells, and then stained with $0.1 \%$ crystal violet for 1 min to see the twitching motility [67].

\subsection{Molecular Identification}

Two isolates (a clinical (C21) and an environmental (E81) isolate) with the highest antibiotic-resistance and the strongest biofilm production were further identified by $16 \mathrm{~S}$ rRNA amplification and sequencing as follows: Overnight broth cultures of the isolated strains were centrifuged for $15 \mathrm{~min}$ at ambient temperature. The supernatants were eliminated, and the pellets were utilized for bacterial DNA extraction using the GeneJET ${ }^{\mathrm{TM}}$ PCR Purification kit (Thermo Scientific) according to the manufacturer's instructions. The dignity of the nucleic acids was evaluated on $1 \%$ agarose gels electrophoresis containing ethidium bromide, and DNA was stored at $-20{ }^{\circ} \mathrm{C}$. PCR amplification using the universal primers 16S-27F (5' AGAGTTTGATCCTGGCTCAG $\left.3^{\prime}\right)$ and 16S-1492R (5'TACGGTTACCTTGTTACGACTT 3') was carried out in a thermal cycler (ABI, Applied Biosystems). Each PCR reaction was conducted using $25 \mu \mathrm{L}$ of Maxima ${ }^{\circledR}$ Hot Start PCR Master Mix (2X), $0.4 \mu \mathrm{L}$ of each primer $(10 \mu \mathrm{M}), 5 \mu \mathrm{L}$ of template DNA, and $18 \mu \mathrm{L}$ nuclease-free water. Reaction without DNA was utilized as a negative control. The $16 \mathrm{~S}$ rRNA gene sequences were compared with the NCBI GenBank database by the Blastn tool in order to identify the two isolates. The two 16S rRNA sequences were submitted to the NCBI database with accession numbers MT772093 and MT772097 for C21and E81, respectively.

\subsection{Phytochemical Studies}

\subsubsection{Plant Material}

A total of seven medicinal plants listed in Table 4 were collected from the Experimental Station of Medicinal and Aromatic Plants, Faculty of Pharmacy, Cairo University, Giza, Egypt in August 2018. The taxonomical features were kindly confirmed by Dr. Abdel-Halem Abdel-mogali, a specialized taxonomist at the agriculture research center, Giza. The plants were air-dried, powdered, and kept tightly closed in glass containers until being extracted.

Table 4. Names of the medicinal plants, their families, and extracted parts used in this study.

\begin{tabular}{ccc}
\hline Names of Medicinal Plant & Family & Extracted Part \\
\hline Rota graveolens & Rutaceae & Aerial part (leaves and flowers) \\
Camellia sinensis & Theaceae & Leaves \\
Olea europaea & Oleaceae & Leaves \\
Styrax benzoin & Styraceae & Resin \\
Humulus lupulus & Cannabaceae & Female inflorescences (hop cones) \\
Ocimum basilicum & Lamiaceae & Aerial part (leaves and flowers) \\
Propolis $($ Apis mellifera $)$ & Apidae & Resin \\
\hline
\end{tabular}

\subsubsection{Preparation and Characterization of Herbal Extracts}

The dried powdered samples of the plants (200-300 g) were extracted with $70 \%$ ethanol by maceration several times until the plant materials were completely exhausted. The ethanolic solutions were filtered and then concentrated using a rotary evaporator under reduced pressure below $50{ }^{\circ} \mathrm{C}$. The extracts were totally dried to obtain semisolid residues. The dried alcoholic plant extracts were stored at $-20^{\circ} \mathrm{C}$ in sealed, tightly closed glass containers. For both Camellia sinensis and Olea europaea alcoholic extracts, qualitative phytochemical analysis according to Savithramma et al. [68] and polyphenol contents using the Folin-Ciocalteu method [69] were carried out. 


\subsubsection{Detection of MIC by the Broth Microdilution Method}

The minimum inhibitory concentrations (MICs) of the active extracts were evaluated against strong-biofilm forming Pseudomonas species only using the broth microdilution method [70]. The Stock solutions of plant extracts were prepared as $100 \mathrm{mg} / \mathrm{mL}$ in dimethyl sulfoxide (DMSO) (twice the required concentration). Serial two-fold dilutions were prepared in Muller Hinton Broth medium (MHB) from $50-0.097 \mathrm{mg} / \mathrm{mL}$ of the plant extracts, and then, an inoculum of bacterial isolates was prepared in BHI broth calibrated to $0.5 \mathrm{McF}$ arland. The experiment was performed in flat-bottom sterile 96-well microtiter plates-initial dispensation of $100 \mu \mathrm{L}$ of bacteria and $100 \mu \mathrm{L}$ of specific concentration of each plant extract. This 96 well plate was further incubated at $37{ }^{\circ} \mathrm{C}$ for $24 \mathrm{~h}$. Each plant extract was investigated for each concentration in triplicates, and the experiment was performed three times independently.

\subsubsection{Growth Curve Analysis}

Growth curve analysis was carried out to evaluate the effect of the sub-MIC of herbal extracts on the growth rates of selected isolates used in this study ( $P$. aeruginosa C21and E81). Overnight cultures of the tested strains were inoculated into $100 \mathrm{~mL}$ of LB broth; OD was set to $0.5 \mathrm{McF}$ arland. Each strain was grown in the presence of sub inhibitory concentrations (1/2 MIC) of each herbal extract concurrent with untreated inoculum as a control. The flasks were incubated at $37^{\circ} \mathrm{C}$, and OD600 was observed at $2 \mathrm{~h}$ intervals for up to $24 \mathrm{~h}$.

\subsubsection{Effect of Subinhibitory Concentrations on Biofilm Formation}

Antibiofilm activity of each plant extract against selected Pseudomonas isolates (C21 and E81) was evaluated at the sub-MIC concentrations (1/2 MIC) using a polystyrene microtiter plate method, as mentioned before, but with some modifications [71]. The sub-MICs amount of each plant extracts was added to the wells; extracts-free wells were used as controls. The percentage of biofilm inhibition was calculated using the following formula:

$$
\% \text { Inhibition }=\frac{\text { OD control }- \text { OD sample }}{\text { OD control }} \times 100
$$

\subsubsection{Effect of Subinhibitory Concentrations on Twitching Motility}

The tested isolates (C21 and E81) were cultured by stabbing into LB agar plates complemented by the sub-MIC (1/2 MIC) of each plant extract using sterile toothpicks, incubated overnight at $37^{\circ} \mathrm{C}$, and then remained for one to two days at room temperature $\left(<25^{\circ} \mathrm{C}\right)$. The diameter of the stained zone $(\mathrm{mm})$ was measured to test the twitching motility; the experiment was carried out in triplicates.

\subsubsection{Effect of Subinhibitory Concentrations on Pyocyanin Production}

The influence of herbal extracts on pyocyanin production by Pseudomonas isolates (C21 and E81) was assayed using a colorimetric method as described before [72]. Pseudomonas isolates (100 $\mu \mathrm{L}$, $10^{6} \mathrm{CFU} / \mathrm{mL}$ ) were inoculated into fresh LB broth and were cultivated in the presence or absence of the sub-MICs (1/2 MIC) of plant extracts incubated at $37^{\circ} \mathrm{C}$ for $24 \mathrm{~h}$. Then, bacterial cultures were centrifuged at $4{ }^{\circ} \mathrm{C}$, and the supernatant was gathered. Chloroform was added to the supernatant, and the mixture was shaken well. The chloroform layer was acidified by $0.2 \mathrm{M} \mathrm{HCl}$ to obtain the pink layer. Then, the absorbance of this layer was measured at $520 \mathrm{~nm}$. Production of pyocyanin was determined as a ratio between the absorbance treated and the absorbance of the control [73]. The most efficient two plant extracts in biofilm formation were selected for the subsequent studies.

$$
\% \text { Inhibition }=\frac{\text { Abs control }- \text { Abs sample }}{\text { Abs control }} \times 100
$$




\subsection{Expression of the QS Genes}

Fluorescence real-time PCR was used to monitor the expression of the QS genes of C21 and E81 in the presence and absence of the selected plant extracts. The primers that were utilized to amplify lasI, lasR, rhlI, rhlR, and 5S RNA (housekeeping gene) were demonstrated in Table 5. Total RNA was extracted in compliance with the manufacturer's instructions of the Quick-RNA ${ }^{\mathrm{TM}}$ MiniPrep extraction kit (Zymo research CORP, Australian). Reverse transcription of the total RNA was performed using a High-Capacity cDNA Reverse Transcription Kit (Thermo-Fischer Scientific). Real-time PCR was conducted using SYBR green kits (SensiFAST SYBR No-ROX Kit, Meridian Life science, UK). The reaction conditions for these genes were as follows: $95^{\circ} \mathrm{C}$ for $15 \mathrm{~min}$ followed by 40 cycles of $95^{\circ} \mathrm{C}$ for $15 \mathrm{~s}, 60^{\circ} \mathrm{C}$ for $30 \mathrm{~s}$, and $72{ }^{\circ} \mathrm{C}$ for $30 \mathrm{~s}$ [19]. The relative fold changes of mRNA levels were measured using the comparative cycle threshold $(\Delta \Delta \mathrm{Ct})$ method for gene expression. The fold change in gene expression was standardized to the reference gene (5S RNA).

Table 5. List of primer sequences used for quantitative Real-time PCR (qRT-PCR).

\begin{tabular}{|c|c|c|c|c|}
\hline Gene & Primer Direction & Sequence $5^{\prime}-3^{\prime}$ & Amplicon Size (bp) & Reference \\
\hline \multirow{2}{*}{ 5S RNA } & Forward & TGACGATCATAGAGCGTTGG & \multirow{2}{*}{121} & \multirow{2}{*}[74]{} \\
\hline & Reverse & GATAGGAGCTTGACGATGACCT & & \\
\hline \multirow{2}{*}{ lasI } & Forward & GTGACGGTAACCACCGTAGG & \multirow{2}{*}{130} & \multirow{2}{*}{ [74] } \\
\hline & Reverse & CTGGGTCTTGGCATTGAGTT & & \\
\hline \multirow{2}{*}{$\operatorname{las} R$} & Forward & CTGTGGATGCTCAAGGACTAC & \multirow{2}{*}{133} & \multirow{2}{*}{ [75] } \\
\hline & Reverse & AACTGGTCTTGCCGATGG & & \\
\hline \multirow{2}{*}{ rhlI } & Forward & AAGGACGTCTTCGCCTACCT & \multirow{2}{*}{130} & \multirow{2}{*}{ [20] } \\
\hline & Reverse & GCAGGCTGGACCAGAATATC & & \\
\hline \multirow{2}{*}{$r h l R$} & Forward & CATCCGATGCTGATGTCCAACC & \multirow{2}{*}{101} & \multirow{2}{*}{ [20] } \\
\hline & Reverse & ATGATGGCGATTTCCCCGGAAC & & \\
\hline
\end{tabular}

\subsection{Statistical Analysis}

The results are demonstrated as the mean values and standard deviations of three separate experiments. All statistical analyses of the variances between the controls and tests were conducted using one-way ANOVA followed by a posthoc Tukey test by GraphPad Prism 8 program, and only results at $p<0.05$ were regarded as significant.

Supplementary Materials: The following are available online at http://www.mdpi.com/2079-6382/9/9/526/s1, Table S1. Antibiotics breakpoint list. The table is showing different antibiotic breakpoints according to CLSI (2016) guidelines. These breakpoints were used to interpret the results of the antibiotic disc diffusion test to determine the sensitivity of our P. aeruginosa isolates to tested antibiotics. Table S2. Qualitative phytochemical analysis and polyphenol contents of ethanol extracts of Camellia sinensis and Olea europaea. Figure S1. Biofilm formation by Pseudomonas isolates on Congo red agar plate. (A): black colonies indicated the EPS production and biofilm formation by P. aeruginosa, while (B) red colonies indicated nonbiofilm producers. Congo red agar is a qualitative method performed onto the agar plate surface. Figure S2. P. aeruginosa growth with and without the sub-MIC of different herpal extracts. (A) the P. aeruginosa (C21) growth curve, while (B) the P. aeruginosa (E81) growth curve treated and untreated with with Camellia sinensis $(3.125 \mathrm{mg} / \mathrm{mL})$, Olea europaea $(6.25 \mathrm{mg} / \mathrm{mL})$, Styrax benzoin (12.5 mg/mL), Humulus lupulus (6.25 mg/mL), Ocimum basilicum $(6.25 \mathrm{mg} / \mathrm{mL})$, Propolis $(6.25 \mathrm{mg} / \mathrm{mL})$, and Ruta graveolans $(12.5 \mathrm{mg} / \mathrm{mL})$ with respect to the control every $2 \mathrm{~h}$ at $37^{\circ} \mathrm{C}$ over $24 \mathrm{~h}$. The data represent the mean value \pm standard deviation and experiments performed in triplicate.

Author Contributions: Conceptualization, R.S. and M.A.R.; data curation, R.S., N.R.E.-S., and L.J.M.A.-H.; formal analysis, R.S., N.R.E.-S., L.J.M.A.-H., and M.A.R.; investigation, R.S., N.R.E.-S., L.J.M.A.-H., and M.A.R.; methodology, R.S., N.R.E.-S., L.J.M.A.-H., and M.A.R.; project administration, R.S., L.J.M.A.-H., and M.A.R.; resources, N.R.E.-s. and L.J.M.A.-H.; software, N.R.E.-s.; supervision, R.S., L.J.M.A.-H., and M.A.R.; validation, L.J.M.A.-H. and M.A.R.; visualization, R.S., N.R.E.-s., and M.A.R.; Writing-original draft, N.R.E.-s. and L.J.M.A.-H.; Writing-review and editing, R.S. and M.A.R. All authors have read and agreed to the published version of the manuscript.

Funding: This research did not receive any specific grant from funding agencies in the public, commercial, or not-for-profit sectors. 
Conflicts of Interest: The authors declare no conflict of interest.

\section{References}

1. Kierbel, A.; Gassama-Diagne, A.; Rocha, C.; Radoshevich, L.; Olson, J.; Mostov, K.; Engel, J. Pseudomonas aeruginosa exploits a PIP3-dependent pathway to transform apical into basolateral membrane. J. Cell Biol. 2007, 177, 21-27. [CrossRef] [PubMed]

2. Mehrad, B.; Clark, N.M.; Zhanel, G.G.; Lynch III, J.P. Antimicrobial resistance in hospital-acquired gram-negative bacterial infections. Chest 2015, 147, 1413-1421. [CrossRef] [PubMed]

3. Sanford, J.A.; Gallo, R.L. Functions of the skin microbiota in health and disease. Semin. Immunol. 2013, 25, 370-377. [CrossRef] [PubMed]

4. McDermott, C.; Chess-Williams, R.; Mills, K.; Kang, S.; Farr, S.; Grant, G.; Perkins, A.; Davey, A.; Anoopkumar-Dukie, S. Alterations in acetylcholine, PGE2 and IL6 release from urothelial cells following treatment with pyocyanin and lipopolysaccharide. Toxicol. Vitro Intern. J. Publ. Assoc. BIBRA 2013, 27, 1693-1698. [CrossRef] [PubMed]

5. Guttenplan, S.B.; Kearns, D.B. Regulation of flagellar motility during biofilm formation. FEMS Microbiol. Rev. 2013, 37, 849-871. [CrossRef]

6. Costerton, J.W.; Cheng, K.; Geesey, G.G.; Ladd, T.I.; Nickel, J.C.; Dasgupta, M.; Marrie, T.J. Bacterial biofilms in nature and disease. Annu. Rev. Microbiol. 1987, 41, 435-464. [CrossRef]

7. Hassett, D.J.; Korfhagen, T.R.; Irvin, R.T.; Schurr, M.J.; Sauer, K.; Lau, G.W.; Sutton, M.D.; Yu, H.; Hoiby, N. Pseudomonas aeruginosa biofilm infections in cystic fibrosis: Insights into pathogenic processes and treatment strategies. Expert. Opin. Ther. Targets 2010, 14, 117-130. [CrossRef]

8. Su, S.; Hassett, D.J. Anaerobic Pseudomonas aeruginosa and other obligately anaerobic bacterial biofilms growing in the thick airway mucus of chronically infected cystic fibrosis patients: An emerging paradigm or “Old Hat"? Expert. Opin. Ther. Targets 2012, 16, 859-873. [CrossRef]

9. Høiby, N.; Bjarnsholt, T.; Givskov, M.; Molin, S.; Ciofu, O. Antibiotic resistance of bacterial biofilms. Int. J. Antimicrob. Agents 2010, 35, 322-332. [CrossRef]

10. Sugano, M.; Morisaki, H.; Negishi, Y.; Endo-Takahashi, Y.; Kuwata, H.; Miyazaki, T.; Yamamoto, M. Potential effect of cationic liposomes on interactions with oral bacterial cells and biofilms. J. Liposome Res. 2016, 26, 156-162. [CrossRef]

11. Dworkin, M.; Falkow, S.; Rosenberg, E.; Schleifer, K.; Stackebrandt, E. The Prokaryotes: Vol. 6: Proteobacteria: Gamma Subclass; Springer: New York, NY, USA, 2006.

12. Kazmierczak, B.I.; Schniederberend, M.; Jain, R. Cross-regulation of Pseudomonas motility systems: The intimate relationship between flagella, pili and virulence. Curr. Opin. Microbiol. 2015, 28, 78-82. [CrossRef] [PubMed]

13. Mattick, J.S. Type IV pili and twitching motility. Annu. Rev. Microbiol. 2002, 56, 289-314. [CrossRef] [PubMed]

14. Wagner, S.; Sommer, R.; Hinsberger, S.; Lu, C.; Hartmann, R.W.; Empting, M.; Titz, A. Novel strategies for the treatment of Pseudomonas aeruginosa infections. J. Med. Chem. 2016, 59, 5929-5969. [PubMed]

15. Lee, J.; Zhang, L. The hierarchy quorum sensing network in Pseudomonas aeruginosa. Protein Cell 2015, 6, 26-41. [CrossRef] [PubMed]

16. Papenfort, K.; Bassler, B.L. Quorum sensing signal-response systems in Gram-negative bacteria. Nat. Rev. Microbiol. 2016, 14, 576-588. [CrossRef]

17. Hurley, M.N.; Cámara, M.; Smyth, A.R. Novel approaches to the treatment of Pseudomonas aeruginosa infections in cystic fibrosis. Eur. Respir. J. 2012, 40, 1014-1023. [CrossRef]

18. Yan, S.; Wu, G. Can Biofilm Be Reversed Through Quorum Sensing in Pseudomonas aeruginosa? Front. Microbiol. 2019, 10, 1582. [CrossRef]

19. Ouyang, J.; Sun, F.; Feng, W.; Sun, Y.; Qiu, X.; Xiong, L.; Liu, Y.; Chen, Y. Quercetin is an effective inhibitor of quorum sensing, biofilm formation and virulence factors in Pseudomonas aeruginosa. J. Appl. Microbiol. 2016, 120, 966-974. [CrossRef]

20. Rajkumari, J.; Borkotoky, S.; Reddy, D.; Mohanty, S.K.; Kumavath, R.; Murali, A.; Suchiang, K.; Busi, S. Anti-quorum sensing and anti-biofilm activity of 5-hydroxymethylfurfural against Pseudomonas aeruginosa PAO1: Insights from in vitro, in vivo and in silico studies. Microbiol. Res. 2019, 226, 19-26. [CrossRef] 
21. Muslim, S.N.; Kadmy, I.M.A.; Ali, A.N.M.; Salman, B.K.; Ahmad, M.; Khazaal, S.S.; Hussein, N.H.; Muslim, S.N. Chitosan extracted from Aspergillus flavus shows synergistic effect, eases quorum sensing mediated virulence factors and biofilm against nosocomial pathogen Pseudomonas aeruginosa. Int. J. Biol. Macromol. 2018, 107, 52-58. [CrossRef]

22. Bjarnsholt, T. The role of bacterial biofilms in chronic infections. Apmis 2013, 121, 1-58. [CrossRef] [PubMed]

23. Zhong, L.; Ravichandran, V.; Zhang, N.; Wang, H.; Bian, X.; Zhang, Y.; Li, A. Attenuation of Pseudomonas aeruginosa Quorum Sensing by Natural Products: Virtual Screening, Evaluation and Biomolecular Interactions. Int. J. Mol. Sci. 2020, 21, 2190. [CrossRef] [PubMed]

24. Nogueira, J.W.A.; Costa, R.A.; da Cunha, M.T.; Cavalcante, T.T.A. Antibiofilm activity of natural substances derived from plants. Afr. J. Microbiol. Res. 2017, 11, 1051-1060.

25. Hnamte, S.; Parasuraman, P.; Ranganathan, S.; Ampasala, D.R.; Reddy, D.; Kumavath, R.N.; Suchiang, K.; Mohanty, S.K.; Busi, S. Mosloflavone attenuates the quorum sensing controlled virulence phenotypes and biofilm formation in Pseudomonas aeruginosa PAO1: In vitro, in vivo and in silico approach. Microb. Pathog. 2019, 131, 128-134. [CrossRef] [PubMed]

26. Paczkowski, J.E.; Mukherjee, S.; McCready, A.R.; Cong, J.-P.; Aquino, C.J.; Kim, H.; Henke, B.R.; Smith, C.D.; Bassler, B.L. Flavonoids suppress Pseudomonas aeruginosa virulence through allosteric inhibition of quorum-sensing receptors. J. Biol. Chem. 2017, 292, 4064-4076. [CrossRef]

27. Koehn, F.E.; Carter, G.T. The evolving role of natural products in drug discovery. Nat. Rev. Drug Discov. 2005, 4, 206-220. [CrossRef]

28. Kostylev, M.; Kim, D.Y.; Smalley, N.E.; Salukhe, I.; Greenberg, E.P.; Dandekar, A.A. Evolution of the Pseudomonas aeruginosa quorum-sensing hierarchy. Proc. Natl. Acad. Sci. USA 2019, 116, 7027-7032. [CrossRef]

29. Malgaonkar, A.; Nair, M. Quorum sensing in Pseudomonas aeruginosa mediated by RhlR is regulated by a small RNA PhrD. Sci. Rep. 2019, 9, 432. [CrossRef]

30. CLSI. Performance Standards for Antimicrobial Susceptibility Testing, 26th ed.; CLSI Supplement M100S; Clinical and Laboratory Standards Institute: Wayne, PA, USA, 2016.

31. Hauser, A.R. Pseudomonas aeruginosa: So many virulence factors, so little time. Crit. Care Med. 2011, 39, 2193-2194. [CrossRef]

32. Paphitou, N.I. Antimicrobial resistance: Action to combat the rising microbial challenges. Int. J. Antimicrob. Agents 2013, 42, S25-S28. [CrossRef]

33. Yayan, J.; Ghebremedhin, B.; Rasche, K. Antibiotic resistance of Pseudomonas aeruginosa in pneumonia at a single university hospital center in Germany over a 10-year period. PLoS ONE 2015, 10, e0139836. [CrossRef] [PubMed]

34. Helal, Z.H.; Hafez, H.M.; Khan, M.I. Susceptibility of Multidrug Resistant Pseudomonas Aeruginosa to Commonly Used Biocides and Its Association with Qac Efflux Pump Genes. Egypt. J. Med. Microbiol. 2015, $38,1-10$.

35. Taha, M.N.; Saafan, A.E.; Ahmedy, A.; El Gebaly, E.; Khairalla, A.S. Two novel synthetic peptides inhibit quorum sensing-dependent biofilm formation and some virulence factors in Pseudomonas aeruginosa PAO1. J. Microbiol. 2019, 57, 618-625. [CrossRef] [PubMed]

36. Ghoneim, E.; Awad, S.; Khalil, M. Prevalence of Multi-Drug Resistant Pseudomonas Spp. and Acinetobacter Spp. causing nosocomial infection in intensive care unit (ICU) of national liver institute. Egypt. J. Med. Microbiol. 2010, 19, 107-118.

37. Abdelraheem, W.M.; Abdelkader, A.E.; Mohamed, E.S.; Mohammed, M.S. Detection of biofilm formation and assessment of biofilm genes expression in different Pseudomonas aeruginosa clinical isolates. Meta Gene 2020, 23, 100646. [CrossRef]

38. El-Khashaab, T.H.; Erfan, D.M.; Kamal, A.; El-Moussely, L.M.; Ismail, D.K. Pseudomonas aeruginosa biofilm formation and quorum sensing lasR gene in patients with wound infection. Egypt. J. Med. Microbiol. 2016, 25, 1-8. [CrossRef]

39. Thilakavathy, P.; Priyan, R.V.; Jagatheeswari, P.; Charles, J.; Dhanalakshmi, V.; Lallitha, S.; Rajendran, T.; Divya, B. Evaluation of ica gene in comparison with phenotypic methods for detection of biofilm production by coagulase negative staphylococci in a tertiary care hospital. J. Clin. Diagn. Res. 2015, 9, DC16-DC19. [CrossRef] 
40. Perez, L.R.R.; Costa, M.; Freitas, A.L.P.d.; Barth, A.L. Evaluation of biofilm production by Pseudomonas aeruginosa isolates recovered from cystic fibrosis and non-cystic fibrosis patients. Braz. J. Microbiol. 2011, 42, 476-479. [CrossRef]

41. Corehtash, Z.G.; Ahmad Khorshidi, F.F.; Akbari, H.; Aznaveh, A.M. Biofilm formation and virulence factors among Pseudomonas aeruginosa isolated from burn patients. Jundishapur J. Microbiol. 2015, 8, e22345.

42. Brackman, G.; Coenye, T. Quorum sensing inhibitors as anti-biofilm agents. Curr. Pharm. Des. 2015, 21, 5-11. [CrossRef]

43. Ahmed, M.N.; Porse, A.; Sommer, M.O.A.; Høiby, N.; Ciofu, O. Evolution of antibiotic resistance in biofilm and planktonic Pseudomonas aeruginosa populations exposed to subinhibitory levels of ciprofloxacin. Antimicrob. Agents Chemother. 2018, 62, e00320-18. [CrossRef] [PubMed]

44. Heydari, S.; Eftekhar, F. Biofilm formation and $\beta$-lactamase production in burn isolates of Pseudomonas aeruginosa. Jundishapur J. Microbiol. 2015, 8, e15514. [CrossRef] [PubMed]

45. Mishra, S.K.; Basukala, P.; Basukala, O.; Parajuli, K.; Pokhrel, B.M.; Rijal, B.P. Detection of biofilm production and antibiotic resistance pattern in clinical isolates from indwelling medical devices. Curr. Microbiol. 2015, 70, 128-134. [CrossRef] [PubMed]

46. Al-Wrafy, F.; Brzozowska, E.; Górska, S.; Gamian, A. Pathogenic factors of Pseudomonas aeruginosa-The role of biofilm in pathogenicity and as a target for phage therapy. Postepy Hig. Med. Dosw. 2017, 71, 78-91. [CrossRef] [PubMed]

47. Bai, L.; Takagi, S.; Ando, T.; Yoneyama, H.; Ito, K.; Mizugai, H.; Isogai, E. Antimicrobial activity of tea catechin against canine oral bacteria and the functional mechanisms. J. Vet. Med. Sci. 2016, 78, 1439-1445. [CrossRef] [PubMed]

48. Souilem, S.; Fki, I.; Kobayashi, I.; Khalid, N.; Neves, M.A.; Isoda, H.; Sayadi, S.; Nakajima, M. Emerging technologies for recovery of value-added components from olive leaves and their applications in food/feed industries. Food Bioproc. Tech. 2017, 10, 229-248. [CrossRef]

49. Taweechaisupapong, S.; Ngaonee, P.; Patsuk, P.; Pitiphat, W.; Khunkitti, W. Antibiofilm activity and post antifungal effect of lemongrass oil on clinical Candida dubliniensis isolate. S. Afr. J. Bot. 2012, 78, 37-43. [CrossRef]

50. Yin, H.; Deng, Y.; Wang, H.; Liu, W.; Zhuang, X.; Chu, W. Tea polyphenols as an antivirulence compound Disrupt Quorum-Sensing Regulated Pathogenicity of Pseudomonas aeruginosa. Sci. Rep. 2015, 5, 16158. [CrossRef]

51. Qais, F.A.; Khan, M.S.; Ahmad, I. Broad-spectrum quorum sensing and biofilm inhibition by green tea against gram-negative pathogenic bacteria: Deciphering the role of phytocompounds through molecular modelling. Microb. Pathog. 2019, 126, 379-392. [CrossRef]

52. Vandeputte, O.M.; Kiendrebeogo, M.; Rajaonson, S.; Diallo, B.; Mol, A.; El Jaziri, M.; Baucher, M. Identification of catechin as one of the flavonoids from Combretum albiflorum bark extract that reduces the production of quorum-sensing-controlled virulence factors in Pseudomonas aeruginosa PAO1. Appl. Environ. Microbiol. 2010, 76, 243-253. [CrossRef]

53. Najee, H.B.; Alkurjia, D.; Almahdawy, O.; Kamerzan, C.; Marutescu, L.; Gheorghe, I.; Marcela, P.; Chifiriuc, M.C.; Veronica, L. Antimicrobial Activity of Olea europaea Fatty Oil against Multi-Drug Resistant and Biofilm Forming Microorganisms. Not. Sci. Biol. 2018, 10, 498-502. [CrossRef]

54. Edziri, H.; Jaziri, R.; Chehab, H.; Verschaeve, L.; Flamini, G.; Boujnah, D.; Hammami, M.; Aouni, M.; Mastouri, M. A comparative study on chemical composition, antibiofilm and biological activities of leaves extracts of four Tunisian olive cultivars. Heliyon 2019, 5, e01604. [CrossRef]

55. Martín-Vertedor, D.; Garrido, M.; Pariente, J.A.; Espino, J.; Delgado-Adámez, J. Bioavailability of bioactive molecules from olive leaf extracts and its functional value. Phytother. Res. 2016, 30, 1172-1179. [CrossRef]

56. Vogel, P.; Machado, I.K.; Garavaglia, J.; Zani, V.T.; de Souza, D.; Dal Bosco, S.M. Polyphenols benefits of olive leaf (Olea europaea L) to human health. Nutr. Hosp. 2015, 31, 1427-1433.

57. Naveed, S.; Hameed, A.; Jaffery, W.Z. Consumption of Green Tea in Professionals and Non-Professionals. Am. J. Drug Deliv. Ther. 2014, 1, 082-088.

58. Ulrey, R.K.; Barksdale, S.M.; Zhou, W.; van Hoek, M.L. Cranberry proanthocyanidins have anti-biofilm properties against Pseudomonas aeruginosa. BMC Complement. Altern. Med. 2014,14,1-12. [CrossRef] 
59. Rasamiravaka, T.; Labtani, Q.; Duez, P.; El Jaziri, M. The formation of biofilms by Pseudomonas aeruginosa: A review of the natural and synthetic compounds interfering with control mechanisms. Biomed. Res. Int. 2015, 2015, 1-17. [CrossRef]

60. Luo, J.; Dong, B.; Wang, K.; Cai, S.; Liu, T.; Cheng, X.; Lei, D.; Chen, Y.; Li, Y.; Kong, J. Baicalin inhibits biofilm formation, attenuates the quorum sensing-controlled virulence and enhances Pseudomonas aeruginosa clearance in a mouse peritoneal implant infection model. PLoS ONE 2017, 12, e0176883. [CrossRef]

61. Luo, J.; Kong, J.-L.; Dong, B.-Y.; Huang, H.; Wang, K.; Wu, L.-H.; Hou, C.-C.; Liang, Y.; Li, B.; Chen, Y.-Q. Baicalein attenuates the quorum sensing-controlled virulence factors of Pseudomonas aeruginosa and relieves the inflammatory response in P. aeruginosa-infected macrophages by downregulating the MAPK and NFKB signal-transduction pathways. Drug Des. Devel. Ther. 2016, 10, 183-203. [CrossRef]

62. Freeman, D.; Falkiner, F.; Keane, C. New method for detecting slime production by coagulase negative staphylococci. J. Clin. Pathol. 1989, 42, 872-874. [CrossRef]

63. Oliveira, A.; Maria de Lourdes, R. Comparison of methods for the detection of biofilm production in coagulase-negative staphylococci. BMC Res. Notes 2010, 3, 1-8. [CrossRef] [PubMed]

64. Stepanović, S.; Vuković, D.; Hola, V.; BONAVENTURA, G.D.; Djukić, S.; Ćirković, I.; Ruzicka, F. Quantification of biofilm in microtiter plates: Overview of testing conditions and practical recommendations for assessment of biofilm production by staphylococci. Apmis 2007, 115, 891-899. [CrossRef] [PubMed]

65. King, E.O.; Ward, M.K.; Raney, D.E. Two simple media for the demonstration of pyocyanin and fluorescin. J. Lab. Clin. Med. 1954, 44, 301-307. [PubMed]

66. O'Toole, G.A.; Kolter, R. Flagellar and twitching motility are necessary for Pseudomonas aeruginosa biofilm development. Mol. Microbiol. 1998, 30, 295-304. [CrossRef] [PubMed]

67. O'May, C.; Tufenkji, N. The swarming motility of Pseudomonas aeruginosa is blocked by cranberry proanthocyanidins and other tannin-containing materials. Appl. Environ. Microbiol. 2011, 77, 3061-3067. [CrossRef]

68. Savithramma, N.; Rao, M.L.; Bhumi, G. Phytochemical screening of Thespesia populnea (L.) Soland and Tridax procumbens L. J. Chem. Pharm. Res. 2011, 3, 28-34.

69. Ivanova, V.; Stefova, M.; Chinnici, F. Determination of the polyphenol contents in Macedonian grapes and wines by standardized spectrophotometric methods. J. Serb. Chem. Soc. 2010, 75, 45-59. [CrossRef]

70. Govan, J.R.; Brown, A.R.; Jones, A.M. Evolving epidemiology of Pseudomonas aeruginosa and the Burkholderia cepacia complex in cystic fibrosis lung infection. Future Microbiol. 2007, 2, 153-164. [CrossRef]

71. Christensen, G.D.; Simpson, W.A.; Bisno, A.L.; Beachey, E.H. Adherence of slime-producing strains of Staphylococcus epidermidis to smooth surfaces. Infect. Immun. 1982, 37, 318-326. [CrossRef]

72. Essar, D.W.; Eberly, L.; Hadero, A.; Crawford, I. Identification and characterization of genes for a second anthranilate synthase in Pseudomonas aeruginosa: Interchangeability of the two anthranilate synthases and evolutionary implications. J. Bacteriol. 1990, 172, 884-900. [CrossRef]

73. Parai, D.; Banerjee, M.; Dey, P.; Chakraborty, A.; Islam, E.; Mukherjee, S.K. Effect of reserpine on Pseudomonas aeruginosa quorum sensing mediated virulence factors and biofilm formation. Biofouling 2018, 34, 320-334. [CrossRef] [PubMed]

74. Lou, Z.; Letsididi, K.S.; Yu, F.; Pei, Z.; Wang, H.; Letsididi, R. Inhibitive effect of eugenol and its nanoemulsion on quorum sensing-mediated virulence factors and biofilm formation by Pseudomonas aeruginosa. J. Food Prot. 2019, 82, 379-389. [CrossRef] [PubMed]

75. Bahari, S.; Zeighami, H.; Mirshahabi, H.; Roudashti, S.; Haghi, F. Inhibition of Pseudomonas aeruginosa quorum sensing by subinhibitory concentrations of curcumin with gentamicin and azithromycin. J. Glob. Antimicrob. Resist. 2017, 10, 21-28. [CrossRef] [PubMed]

(C) 2020 by the authors. Licensee MDPI, Basel, Switzerland. This article is an open access article distributed under the terms and conditions of the Creative Commons Attribution (CC BY) license (http://creativecommons.org/licenses/by/4.0/). 